\title{
Spatial modeling of haul-out site use by harbor seals in Cook Inlet, Alaska
}

\author{
R. A. Montgomery, J. M. Ver Hoef, P. L. Boveng* \\ Polar Ecosystems Program, National Marine Mammal Laboratory, Alaska Fisheries Science Center, \\ 7600 Sand Point Way NE, Bldg 4, Seattle, Washington 98115-6349, USA
}

\begin{abstract}
Harbor seals Phoca vitulina haul out on land to give birth to and rear their pups, rest, escape aquatic predation and molt. The choice of a haul-out site is therefore fundamental to survival and reproduction. Aerial surveys of harbor seals were conducted in Cook Inlet, Alaska, to investigate the seals' selection of various environmental characteristics of haul-out sites. Eight surveys from April, June, August and October were performed to understand how haul-out site use varies seasonally. A GIS database describing all potential haul-out habitats in the study area was created by acquiring separate data sets on bathymetry, sea-bed type, proximity to sources of anthropogenic disturbance, prey availability, biological wave exposure and substrate type. Because harbor seal abundance and several environmental features varied temporally, 4 separate models were developed to account for conditions specific to each survey month. Spatial regression analyses, which allowed data to be spatially autocorrelated, were used to identify the relationships between harbor seal abundance and environmental variables associated with haul-out sites. Harbor seals were found to haul out near available prey and to avoid areas high in anthropogenic disturbance. The seals also selected haul-out sites of rock substrate and those that were near deep water.
\end{abstract}

KEY WORDS: Spatial regression · Seals · Haul-out behavior · Spatial autocorrelation · Habitat Resale or republication not permitted without written consent of the publisher

\section{INTRODUCTION}

Harbor seals Phoca vitulina are semi-aquatic mammals (Pitcher \& McAllister 1981) that depend upon the marine environment for their food supply, but haul out on land or ice to perform many of their most fundamental behaviors (Watts 1996). They haul out to rest (da Silva \& Terhune 1988), maintain skin health (Feltz \& Fay 1966), molt (Ling 1984), play (Renouf \& Lawson 1986), escape aquatic predation (Watts 1992) and give birth to and rear their pups (Thompson 1989). These ultimate explanations of haul-out behavior are well known, but the proximate mechanism of haul-out site selection remains largely unknown. The main goal of this study was to determine relationships between environmental variables and the selection of haul-out sites by harbor seals.

Most studies of harbor seal haul-out use focus on the ways that date, time of day, tide conditions and weather impact harbor seal abundance (Boveng et al. 2003, Simpkins et al. 2003). Some studies have suggested certain factors that could be important in the selection of a haul-out site. Researchers have proposed that harbor seals select sites that are low in disturbance (Schneider \& Payne 1983, Thompson 1989), close to available prey (Scheffer \& Slipp 1944), protected from wind exposure (Bjørge et al. 2002) and with access to deep water (Scheffer \& Slipp 1944, Sullivan 1980). Our specific goal, then, was to investigate the importance of these and other factors in the selection of haul-out sites by harbor seals.

To determine the abundance and distribution of harbor seals hauled out along the shores of Cook Inlet, Alaska, we conducted aerial surveys. These surveys were performed during the summer months of June and August, when harbor seals hauled out in greater numbers (Sullivan 1980, Jemison \& Kelly 2001), as well as April and October, when the numbers of seals 
ashore were typically lower. We created a GIS database of different environmental variables describing the habitat of Cook Inlet. We developed 4 seasonally specific models that assumed spatially autocorrelated error structures. With these models we were able to determine which environmental variables harbor seals selected when hauling out on land.

\section{MATERIALS AND METHODS}

Study area. The study area included central and lower Cook Inlet, Alaska, with the northern boundary at the forelands near the village of Nikiski and the southern boundary at Cape Douglas (Fig. 1). Cook Inlet is a tidal estuary with a predominantly northto-south orientation that opens into the Gulf of Alaska via the Shelikof Strait and the Kennedy and Stevenson entrances (Muench et al. 1978). It has an area of $20000 \mathrm{~km}^{2}$ with $1350 \mathrm{~km}$ of coastline (Rugh et al. 2000). The coastline has a variety of different substrates, with reefs and rock more common in the south

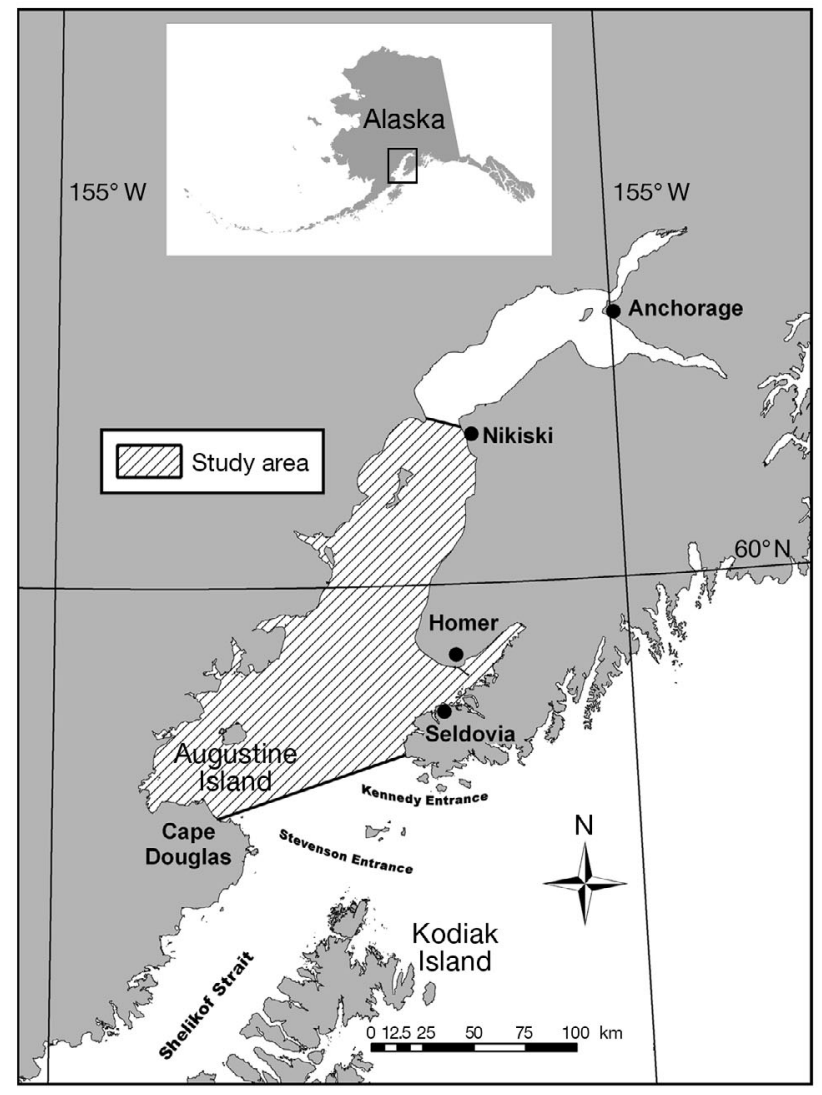

Fig. 1. Study area in central and lower Cook Inlet, Alaska, where coastal aerial surveys were performed. Aerial surveys were conducted in all areas between the northern boundary near the village of Nikiski and the southern boundary at Cape Douglas and with mudflats almost exclusively in the north. Cook Inlet has a mean depth of close to $60 \mathrm{~m}$ (Muench et al. 1978), tides that range from 6 to $9 \mathrm{~m}$ and currents as high as 12 knots (Moore et al. 2000).

Aerial surveys. A total of 8 aerial surveys (April 2004 \& 2005, June 2003 \& 2004, August 2003 \& 2004 and October 2003 \& 2004) were flown from 2003 to 2005. Each aerial survey typically lasted 7 to $10 \mathrm{~d}$, with the first couple of days consisting of a comprehensive search of the entire coastline to identify all Phoca vitulina haul-out sites. An area where at least 1 seal had hauled out on at least $1 \mathrm{~d}$ constituted a haul-out site (Fig. 2). The position of each haul-out site was marked with a GPS unit, and the site was revisited on multiple days over the remainder of the survey.

Each flight was conducted from $2 \mathrm{~h}$ before low tide to $2 \mathrm{~h}$ after low tide, when harbor seals are more likely to be hauled out (Allen et al. 1984, Watts 1996, Bjørge et al. 2002, Boveng et al. 2003). Due to the large size of Cook Inlet, the study area was divided into 2 routes to allow complete coverage each day. The northern route was flown with a single engine plane (Cessna 185 or Cessna L-19) that maintained a speed of 80 to 100 knots. The southern route was flown with a twin engine plane (AC-680 or AC-690) that maintained a speed of 110 to 130 knots. The flights were conducted at altitudes of 150 to $275 \mathrm{~m}$.

Haul-out sites with $<10$ harbor seals were often counted visually, but larger haul-outs were photo-

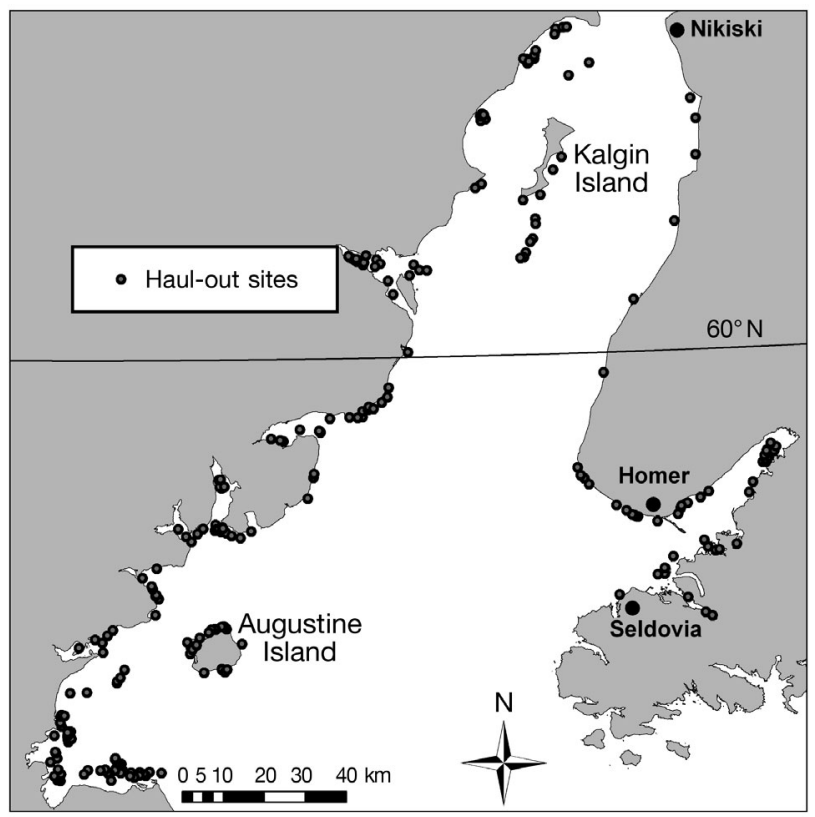

Fig. 2. Phoca vitulina. Distribution of harbor seal haul-out sites in Cook Inlet. Points on map represent sites where at least 1 seal was observed on at least 1 survey day. All other areas were devoid of seals throughout all of the 8 aerial surveys 
graphed. Seals in the photographs were counted in the laboratory using digital editing programs (ACDSee and Adobe Photoshop CS). Any observations in which the count was compromised as a result of site disturbance or low picture quality were removed. Pups, which could be visually identified in June, were also excluded from the analysis. As pups were completely dependent upon their mothers in the month of June, it was assumed that they did not make a selection for a haul-out site. Young-of-the-year, those seals weaned from their mother in the year of their birth, were included in the analysis of the months of August, October and April, when they would be making independent haul-out site selections.

GIS analysis. Habitat unit structure: To model the terrestrial habitat use of harbor seals in Cook Inlet, we first identified all available haul-out areas. In estuaries, the intertidal range commonly presents the only suitable haul-out habitat for harbor seals (Thompson et al. 1997). In Cook Inlet, this intertidal range is between the mean high tide line $(+5 \mathrm{~m})$ and the extreme low tide line $(-2 \mathrm{~m})$. Using fine-scale bathymetry and coastal contour line data, this area was isolated. We then added a uniform grid structure at a resolution of $500 \mathrm{~m}^{2}$ over the whole study area in ArcMap 9.0. This grid lattice was clipped to the intertidal range so that only available haul-out space was divided into cells. We then aggregated the clipped grid cells into larger sample units to match the scale of the environmental variables. To spatially aggregate grid cells into sample units, we used SAS PROC FASTCLUS (Version 9.1) to cluster according to the presence or absence of haulout sites, the spatial coordinates of each cell and the maximum number of clusters. The result of this operation was 224 habitat units, covering all available haulout area in central and lower Cook Inlet (Fig. 3).

Abundance data: We used the average count of harbor seals at each habitat unit within a given survey as the response variable. The data included some zeros in habitat units where harbor seals were not observed.

Substrate and biological wave exposure: A substrate and biological wave exposure dataset was used to determine whether seals selected certain substrate or wave exposure types more often than others. This dataset, derived from shore zone aerial surveys of the coastline of the Gulf of Alaska, was provided by Coastal and Ocean Resources Inc. (CORI). Biological wave exposure was interpolated from the presence or absence of certain faunal assemblages and consisted of 5 main groups (semi-exposed, exposed, protected, semiprotected and very protected). The substrate layer originally included 13 different categories. For simplicity, we combined these data into 6 broader classes (gravel, mud, mud/gravel, rock, sand and sand/rock). As there were often a number of different classes of substrate

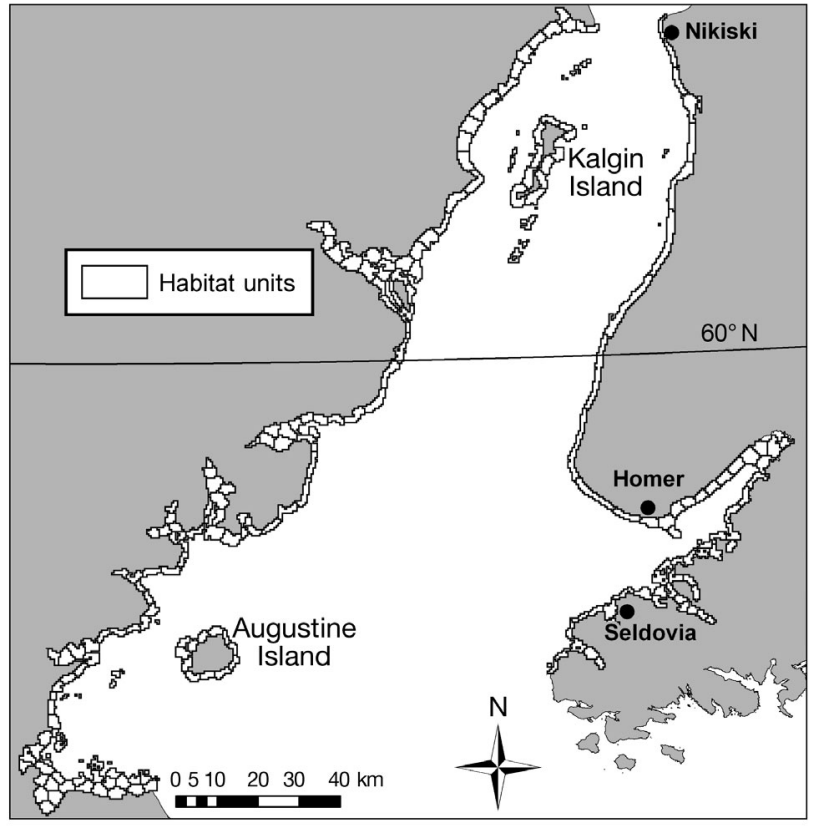

Fig. 3. Phoca vitulina. Harbor seal habitat units covering all available haul-out area in central and lower Cook Inlet. There were a total of 224 habitat units throughout the Inlet covering the intertidal habitat between -2 and $+5 \mathrm{~m}$

and wave exposure within a given habitat unit, each unit was assigned the value of the substrate or wave exposure type that composed the majority of the total.

Distance to water depths: A bathymetric data file from NOAA Electronic Navigation Charts (NOAA ENC) consisting of $>28000$ depth soundings was used to analyze the relationship between haul-out sites and distance to water of various depths. We converted the dataset to a raster at a cell size of $100 \mathrm{~m}$. To analyze any potential relationships that might exist between haul-out site selection and bathymetry, we isolated 2 depths. Distances were calculated in meters from all habitat units to the closest points of 20 and $60 \mathrm{~m}$ in depth. These isolated depths allowed us to observe the relationship between harbor seal abundance at haulout sites and deep water drop offs. In the small number of cases where this distance was calculated over land, a route that a harbor seal would be unable to use, we measured the shortest path by sea manually.

Distance to seabed type: We used a dataset of seabed type provided by the National Imagery and Mapping Agency (NIMA) to investigate the relationship between harbor seal abundance and seabed type. Cook Inlet had 3 predominant seabed types: rock, mud and sand. Distances were calculated in meters from each habitat unit to the closest point of all seabed types. In the small number of cases where this distance was calculated over land, the shortest path by sea was measured manually. 
Anthropogenic disturbance: In Cook Inlet there were several different sources of anthropogenic disturbance. We focused on the relationship between the abundance of harbor seals and the distance to human communities. This was an effort to understand how harbor seals used haul-out sites in relation to human communities. We calculated the distance by sea from each habitat unit to coastal Cook Inlet communities. These communities included Homer, Kachemak, Kasilof, Anchor Point, Clam Gulch, Kenai, Nanwalek, Nikiski, Ninilchik, Port Graham, Salamatof, Seldovia and Seldovia Village. A correlation calculation was performed to test the degree of collinearity amongst the variables. As the distances to some of these communities were highly correlated $(r>0.7)$ among the habitat units, we revised the analysis to include only the distance from each habitat unit to the closest human community. This reduced the collinearity in the model.

Distance to anadromous fish stream: The Alaska Department of Fish and Game's Sport Fish Division provided the Fish Distribution Database (FDD) that contained information on the spatial distribution of potential harbor seal prey. All 5 species of Pacific salmon Oncorhynchus spp. are found in Cook Inlet (Vos 2003) as well as steelhead trout Oncorhynchus mykiss and Dolly Varden Salvelinus malma. The presence of these species varies seasonally, so the model for each of the 4 months included only those species that were present during the corresponding month of the aerial surveys. We calculated distances by sea from each habitat unit to the closest anadromous fish stream. Dolly Varden was excluded from the analysis because it was highly correlated $(\mathrm{r}>0.7)$ with the distance-to-community variable.

Spatial regression analysis. Our analysis modeled the effect of environmental variables on the distribution and abundance of hauled-out harbor seals. Data from 8 aerial surveys were used to create 4 seasonal models. The data were modeled as a spatial regression (e.g. Ver Hoef et al. 2001):

$$
Y_{i}=x_{i}^{\prime} \beta+Z_{i}
$$

where $Y_{i}$ was the response variable (harbor seal abundance) at the $i$ th habitat unit, $\mathrm{x}_{i}$ was a vector of the observed values of the explanatory variables at the $i$ th habitat unit, $\beta$ was a vector of regression parameters and $Z_{i}$ was a random error with zero mean and covariance that was spatially autocorrelated. Note that our model is similar to spatial models for regional disease mapping and lattice data (see e.g. Cressie 1993, p. 383), where point locations (hauled-out seals) have been aggregated to a count for a habitat unit. All effects of seal interactions within the scale of a habitat unit have been subsumed by aggregation. The model is then built for the variation in counts among habitat units, which occurs at a larger scale (Taylor \& Goddard 1974). After accounting for the covariates in the model, any factors causing association at this scale, including seal interactions, are absorbed by spatial autocorrelation.

The response variable of harbor seal abundance was not normally distributed due to the presence of some zeros and several large values in the data. To satisfy the assumptions of the linear regression model, it was important for the residuals to closely approximate a normal distribution. We found a good approximation when all counts were log transformed [log(average count +1$)$ ]. All explanatory variables that were distance calculations (in meters) were divided by 1000 to reduce round off or other numerical complications of large numbers.

Our model of autocorrelation among the random errors $Z_{i}$ relied on the distances between locations, which we took to be the distances between the centroids of the habitat units in Fig. 3. For the autocorrelated errors, we used a spherical covariance model (Cressie 1993, p. 61) that allowed for anisotropy. For our data, anisotropy was evident because the data exhibited directional spatial dependence (Ripley 1981). We used restricted maximum likelihood (REML, e.g. Ver Hoef et al. 2001) to estimate model parameters, using SAS PROC MIXED (Version 9.1). REML has less bias than maximum-likelihood estimation (Mardia \& Marshall 1984). All p-values for explanatory variables were based on the Type III hypothesis test in SAS, which tests each effect after all others; we used an $F$ distribution with $n-r$ denominator degrees of freedom, where $n$ is the sample size and $r$ is the rank of the design matrix. The models consisted of the continuous response variable of harbor seal abundance and 14 different explanatory variables (Table 1).

Separate models were fit for April, June, August and October and analyzed using spatial regression. Following Ver Hoef et al. (2001), variables with $p>0.15$ were removed one at a time, starting with the least significant variable. This step-wise regression continued until the final model structure included all variables with $\mathrm{p}<0.15$. Final statistical significance was based on $\mathrm{p}<0.05$. Note that because we used REML, which integrates fixed effects out of the likelihood, it was not possible to use Akaike's information criterion (AIC) to choose for the fixed effect terms, our primary focus in these models. Although Hoeting et al. (2006) mentioned the possibility of selecting models using maximum likelihood and AIC, and then making the final fit using REML, this has not been tested in theory or practice. Therefore, for our spatial regression using REML, we used the traditional approach of stepwise selection of fixed effects. 


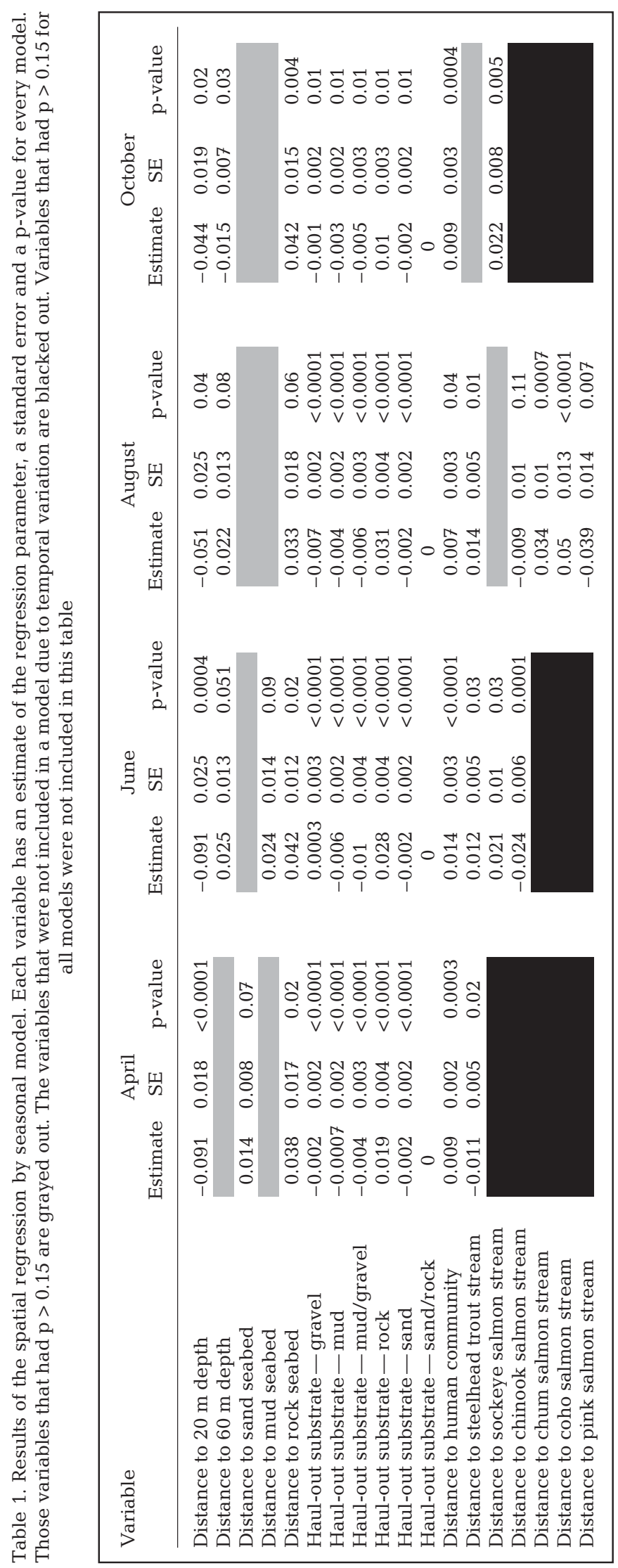

\section{RESULTS}

\section{Spatial regression analysis}

\section{April model}

In the April model, wave exposure ( $\mathrm{p}=0.92)$, distance to mud seabed type $(\mathrm{p}=0.91)$, distance to $60 \mathrm{~m}$ in depth $(p=0.37)$ and survey year $(p=0.33)$ were eliminated from the final model (Table 1). The results of the model showed that abundance of hauled-out harbor seals Phoca vitulina increased in proximity to water $20 \mathrm{~m}$ in depth $(\mathrm{p} \leq 0.0001)$. Distance to sand seabed type was not statistically significant $(p=0.07)$. Distance to rock seabed type was significant $(p=0.02)$ and harbor seal abundance at haul-out sites increased with distance from this seabed type. Haul-out substrate was significant ( $\mathrm{p} \leq 0.0001)$, and more harbor seals used rock substrates than any other substrate type. The remaining substrate types in descending order of their effects were sand/rock, mud, gravel, sand and mud/ gravel. More harbor seals were hauled out far away from Cook Inlet communities ( $p=0.0003)$, and abundance of harbor seals increased close to steelhead trout Oncorhynchus mykiss streams ( $\mathrm{p}=0.02)$.

The regression coefficients for the distance variables were estimates of the expected change in the log average abundance of harbor seals for a unit change in distance, with all other variables held constant. There was a 0.091 decrease in the log average abundance of harbor seals with every $1 \mathrm{~km}$ move away from the nearest point of $20 \mathrm{~m}$ in depth (Table 1). A 0.009 decrease in the log average abundance of harbor seals was found with every $1 \mathrm{~km}$ move closer to human communities. Also there was a 0.011 decrease in the log average abundance of harbor seals with every $1 \mathrm{~km}$ move away from steelhead trout streams.

\section{June model}

In the June model, wave exposure ( $p=0.99)$, survey year $(\mathrm{p}=0.86)$ and distance to sand seabed type $(\mathrm{p}=$ 0.58 ) were excluded from the final model (Table 1). Distance to $20 \mathrm{~m}$ in depth was highly significant $(\mathrm{p}=$ 0.0004 ), and abundance of harbor seals increased at haul-out sites close to this depth. Distance to $60 \mathrm{~m}$ in depth $(\mathrm{p}=0.051)$ and distance to mud seabed type $(\mathrm{p}=$ $0.09)$ were not statistically significant. Distance to rock seabed type was significant $(p=0.02)$, and abundance of harbor seals increased with distance from this seabed type. Haul-out substrate was highly significant ( $p \leq 0.0001)$, with the greatest number of seals using rock. The remaining substrate types in descending order of their effects were gravel, sand/rock, sand, 
mud and mud/gravel. Distance to community was very significant ( $p \leq 0.0001)$, with an increased abundance of harbor seals at haul-out sites far away from Cook Inlet communities. Additionally, distance to chinook salmon Oncorhynchus tshawytscha streams $(\mathrm{p}=$ $0.0001)$, steelhead trout $O$. mykiss streams $(\mathrm{p}=0.03)$ and sockeye salmon $O$. nerka streams $(p=0.03)$ were significant. However, distance to chinook salmon streams was the only relationship where greater numbers of harbor seals used haul-out sites close to this prey source.

The parameter estimates for the explanatory variables indicated that a 0.091 decrease in the log average abundance of harbor seals occurred with every $1 \mathrm{~km}$ move away from $20 \mathrm{~m}$ in depth (Table 1). A 0.014 decrease in the log average abundance of harbor seals was found with every $1 \mathrm{~km}$ move closer to human communities. Also there was a 0.024 decrease in the log average abundance of harbor seals with every $1 \mathrm{~km}$ move away from chinook salmon streams.

\section{August model}

In the August model, distance to sockeye salmon streams $(p=0.96)$, wave exposure $(p=0.91)$, survey year $(p=0.85)$, distance to sand seabed type $(p=0.70)$ and distance to mud seabed type $(p=0.72)$ were excluded from the final model due to insignificance (Table 1). The final model demonstrated that harbor seal abundance increased close to $20 \mathrm{~m}$ in depth $(\mathrm{p}=$ $0.04)$. Distance to rock seabed type was not statistically significant $(p=0.06)$ and neither was distance to $60 \mathrm{~m}$ in depth $(p=0.08)$. Haul-out substrate was highly significant ( $p \leq 0.0001$ ), and more harbor seals used rock substrates than any other type. The remaining substrate types in descending order of their effects were sand/rock, sand, mud, mud/gravel and gravel. Distance to community was significant $(p=0.04$ ), and more seals used haul-out sites far away from the communities. Harbor seal abundance increased at haul-out sites close to pink salmon Oncorhynchus gorbuscha streams $(p=0.007)$. The relationship with chinook salmon streams $(p=0.11)$ was not statistically significant. Distance to chum salmon $O$. kisutch streams ( $p=0.0007$ ), distance to coho salmon $O$. keta streams ( $p \leq 0.0001)$ and distance to steelhead trout streams $(p=0.01)$ were significant with more harbor seals at haul-out sites farther away from these streams.

The parameter estimates for the explanatory variables revealed that there was a 0.051 decrease in the log average abundance of harbor seals with every $1 \mathrm{~km}$ move away from $20 \mathrm{~m}$ in depth (Table 1). A 0.007 decrease in the log average abundance of harbor seals was found with every $1 \mathrm{~km}$ move closer to human communities. Also there was a 0.039 decrease in the log average abundance of harbor seals with every $1 \mathrm{~km}$ move away from pink salmon streams.

\section{October model}

In the October model, wave exposure $(p=0.99)$, distance to mud seabed type $(p=0.90)$, survey year $(p=$ $0.69)$, distance to sand seabed type $(p=0.44)$ and distance to steelhead trout streams $(p=0.31)$ were removed due to insignificance (Table 1). Abundance of harbor seals increased at haul-out sites close to $20 \mathrm{~m}$ in depth $(\mathrm{p}=0.02)$. Distance to $60 \mathrm{~m}$ in depth $(\mathrm{p}=0.03)$ was also significant, and harbor seal abundance increased at haul-out sites near this bathymetric depth. Distance to rock seabed type was significant $(p=0.004)$, and abundance of harbor seals increased at haul-out sites that were far away from this variable. Haul-out substrate was statistically significant $(p=0.01)$, and abundance of harbor seals increased on rock substrate. The remaining substrate types in descending order of their effects were sand/rock, gravel, sand, mud and mud/gravel. Numbers of harbor seals increased with distance from human communities in Cook Inlet ( $p=$ 0.0004). Distance to sockeye salmon streams was significant ( $p=0.005)$, with increased abundance of harbor seals at haul-out sites far away from sockeye streams.

The parameter estimates for the explanatory variables revealed that there was a 0.044 decrease in the log average abundance of harbor seals with every $1 \mathrm{~km}$ move away from $20 \mathrm{~m}$ in depth (Table 1). A 0.009 decrease in the log average abundance of harbor seals was found with every $1 \mathrm{~km}$ move closer to human communities. Also there was a 0.015 decrease in the log average abundance of harbor seals with every $1 \mathrm{~km}$ move away from $60 \mathrm{~m}$ in depth.

\section{Model comparison}

The 4 models differed in the amounts of residual variation attributed to spatially autocorrelated errors (in geostatistics this is called the 'partial sill'; Cressie 1993) versus uncorrelated errors (in geostatistics this is called the 'nugget'; Cressie 1993) (Table 2). The total variance, also called the sill, is the sum of the nugget and partial sill. The ratio of the partial sill to the total variance is the proportion of residual variation that is due to spatial autocorrelation. Table 2 shows that April and October had smaller proportions (around 75\%) of spatially autocorrelated residual variation than June and August (around 95\%), but in all cases spatially autocorrelated variation was dominant over uncorrelated variation in the spatial regression analyses. 
Table 2. Covariance parameter estimates from the 4 different models. The 'partial sill' estimates the spatially structured variation of the model, while the 'nugget' estimates the uncorrelated variation. The ratio of the partial sill to the sum of partial sill and nugget provides a measure of each model's level of spatial autocorrelation

\begin{tabular}{|lccc|}
\hline Month & Partial sill & Nugget & Ratio \\
\hline Apr & 1.14 & 0.34 & 0.77 \\
Jun & 2.03 & 0.0006 & 0.99 \\
Aug & 2.24 & 0.21 & 0.91 \\
Oct & 1.12 & 0.37 & 0.75 \\
\hline
\end{tabular}

\section{DISCUSSION}

This spatial regression analysis revealed that certain environmental variables were important for harbor seal Phoca vitulina haul-out site use. Abundance of harbor seals was greater at haul-out sites that were farther away from Cook Inlet communities, closer to bathymetric depths of $20 \mathrm{~m}$ and near available prey. Additionally, seals tended to use haul-out sites with rock substrate more often than any other substrate type.

All of the month-specific models indicated that abundance of harbor seals was higher at haul-out sites that were farther away from coastal Cook Inlet communities. This result seems logical, as human populations are associated with foot traffic (Kenyon 1972, Moss 1992), car traffic, boat traffic (Allen et al. 1984, Watts 1996), air traffic (Moore et al. 2000) and pollution (Reijnders 1984). Anthropogenic disturbance can lead seals to avoid or completely abandon haul-out areas (Sullivan 1980, da Silva \& Terhune 1988). In each model there was a 0.014 to 0.009 decrease in the log average abundance of harbor seals with every $1 \mathrm{~km}$ move closer to the coastal Cook Inlet communities. This result supports the notion that harbor seals tend to select sites farther away from human communities.

Harbor seal abundance increased with increasing proximity to a bathymetric depth of $20 \mathrm{~m}$. This result illustrates that harbor seals selected sites close to deep water, as previously suggested (Scheffer \& Slipp 1944, Sullivan 1980). Access to deep water could be advantageous for a couple of reasons. It could lead to a greater availability of hunting opportunities for pelagic fish species such as walleye pollock Theragra chalcogramma and Pacific herring Clupea pallasi (Pitcher 1980). Both species are found in the Gulf of Alaska (Sturdevant et al. 2001), including Cook Inlet (Abookire et al. 2000), and are a preferred prey of harbor seals (Pitcher 1977). Access to deep water could also afford greater escapement from disturbance or predation risk (Scheffer \& Slipp 1944). This variable was important in this analysis as there was a 0.044 to 0.091 decline in the log average abundance of harbor seals with every $1 \mathrm{~km}$ move away from waters $20 \mathrm{~m}$ in depth.

Selection of aquatic feeding grounds is vital to harbor seals (Matthiopoulos et al. 2004). The distribution of prey has a direct impact on the distribution and abundance of predators (Womble et al. 2005). The changing levels of anadromous fish, for instance, cause seals and sea lions to modify their location and habits (Willson \& Halupka 1995). Our analysis revealed that harbor seals used haul-out sites that were close to steelhead trout streams in April, close to chinook salmon streams in June and close to pink salmon streams in August. These results show that harbor seals adapted to the temporal variation of anadromous prey and used haul-out sites that were close to available fish streams. October was the only month in which harbor seals were not found to use haul-out sites close to seasonal anadromous fish streams. However, in October, harbor seals were more abundant near waters of $60 \mathrm{~m}$ in depth. These 2 results suggest that in October harbor seals rely less on the seasonally reduced runs of anadromous fish and make more use of the pelagic water column. This conclusion is also supported by the fact that harbor seal abundance at haul-out sites drops off dramatically following the August molt (Sullivan 1980, Boveng et al. 2003, Ver Hoef \& Frost 2003), when animals begin spending more time at sea.

Our study showed that harbor seals selected haulout sites with rock substrates more often than any other substrate type. This result is consistent with previous studies. Harbor seal pups have been found to select rock haul-outs adjacent to islands that act as a wind break (Bjørge et al. 2002). Schneider \& Payne (1983) also noted that harbor seal abundance was greater on large offshore rocks.

Previous studies found that harbor seals avoid areas high in wave action (Sullivan 1980), yet we did not find a relationship between harbor seal haul-out abundance and biological wave exposure. This could be a result of the scale of the study. Future analyses might find relationships if they use habitat units at a scale that is more similar to that of the biological wave exposure layer.

This quantitative analysis revealed that harbor seals in Cook Inlet select specific environmental variables when identifying habitat that is appropriate for hauling out. Spatial regression confirmed that access to deep water, distance to anadromous fish streams, substrate type and anthropogenic disturbance are all important variables in the selection of appropriate haul-out habitat by harbor seals. Researchers conducting surveys in unfamiliar areas could use this analysis to predict spatial distributions of harbor seals, and this line of research could be replicated in other areas to determine how the selection of habitat varies across space. 
Acknowledgements. We thank the following people for being observers in our aerial surveys and for counting seals in survey images: D. Withrow, J. Jansen, S. Dahle, M. Simpkins, J. DeGroot, O. Badajos and B. Jenkinson. Aerial surveys were flown with Northwind Aviation, Commander Northwest and Suburban Air Freight. This study was supported by the Minerals Management Service and the NOAA National Marine Fisheries Service under Interagency Agreement MMS 0103RU72448. NOAA's Office of Fisheries Information Systems, the Alaska Department of Fish and Game and CORI granted use of their datasets to describe harbor seal habitat in Cook Inlet. We are grateful to J. Bengtson, K. Raedeke and 3 anonymous reviewers for helpful critiques of this manuscript.

\section{LITERATURE CITED}

Abookire AA, Piatt JF, Robards MD (2000) Nearshore fish distribution in an Alaskan estuary in relation to stratification, temperature and salinity. Estuar Coast Shelf Sci 51:45-59

Allen SG, Ainley DG, Page GW, Ribic CA (1984) The effect of disturbance on harbor seal haul out patterns at Bolinas Lagoon, California. Fish Bull 82:493-500

Bjørge A, Bekkby T, Bryant EB (2002) Summer home range and habitat selection of harbor seal (Phoca vitulina) pups. Mar Mamm Sci 18:438-454

Boveng PL, Bengtson JL, Cesarone JC, Simpkins MA, Frost KJ, Burns JJ (2003) The abundance of harbor seals in the Gulf of Alaska. Mar Mamm Sci 19:111-127

Cressie NA (1993) Statistics for spatial data, revised edn. Wiley, New York

da Silva J, Terhune JM (1988) Harbour seal grouping as an anti-predator strategy. Anim Behav 36:1309-1316

Feltz ET, Fay FH (1966) Thermal requirements in vitro of epidermal cells from seals. Cryobiology 3:261-264

Hoeting JA, Davis RA, Merton AA, Thompson SE (2006) Model selection for geostatistical models. Ecol Appl 16:87-98

Jemison LA, Kelly BP (2001) Pupping phenology and demography of harbor seals (Phoca vitulina richardsi) on Tugidak Island, Alaska. Mar Mamm Sci 17:585-600

Kenyon KW (1972) Man versus the monk seal. J Mamm 53: 687-696

Ling JK (1984) Epidermal cycles and moulting in marine mammals. Acta Zool Fenn 171:23-26

Mardia KV, Marshall RJ (1984) Maximum likelihood estimation of models for residual covariance in spatial regression. Biometrika 71:135-146

Matthiopoulos J, McConnell BJ, Duck C, Fedak MA (2004) Using satellite telemetry and aerial counts to estimate space use by grey seals around the British Isles. J Appl Ecol 41: 476-491

Moore SE, Shelden KW, Litzky LK, Mahoney BA, Rugh DJ (2000) Beluga, Delphinapterus leucas, habitat associations in Cook Inlet, Alaska. Mar Fish Rev 62:60-80

Moss J (1992) Environmental and biological factors that influence harbor seal (Phoca vitulina richardsi) haulout behavior in Washington and their consequences for the design of population surveys. MS thesis, University of Washington, Seattle, WA

Muench RD, Mofjeld HO, Charnell RL (1978) Oceanographic conditions in lower Cook Inlet: spring and summer 1973. J Geophys Res 83:5090-5098

Pitcher KW (1977) Population productivity and food habits of

Editorial responsibility: Howard Browman (Associate Editorin-Chief), Storebø, Norway harbor seals in the Prince William Sound-Copper River Delta area, Alaska. Report MM5AC011 to US Marine Mammal Commission

Pitcher KW (1980) Food of the harbor seal Phoca vitulina richardsi in the Gulf of Alaska. Fish Bull 78:544-549

Pitcher KW, McAllister DC (1981) Movements and haulout behavior of radio-tagged harbor seals, Phoca vitulina. Can Field-Nat 95:292-297

Reijnders PJH (1984) Man-induced environmental factors in relation to fertility changes in pinnipeds. Environ Conserv 11:61-65

Renouf D, Lawson JW (1986) Play in harbour seals (Phoca vitulina). J Zool Soc Lond 208:73-82

Ripley BD (1981) Spatial statistics. John Wiley \& Sons, New York

Rugh DJ, Shelden KEW, Mahoney BA (2000) Distribution of belugas, Delphinapterus leucas, in Cook Inlet, Alaska, during June/July 1993-2000. Mar Fish Rev 62:6-21

Scheffer VB, Slipp JW (1944) The harbor seal in Washington state. Am Midl Nat 32:373-416

Schneider DC, Payne PM (1983) Factors affecting haul-out of harbor seals at a site in southeastern Massachusetts. J Mamm 64:518-520

Simpkins MA, Withrow DE, Cesarone JC, Boveng PL (2003) Stability in the proportion of harbor seals hauled out under locally ideal conditions. Mar Mamm Sci 19:791-805

Sturdevant MV, Brase ALJ, Hulbert LB (2001) Feeding habits, prey fields, and potential competition of young-of-theyear walleye pollock (Theragra chalcogramma) and Pacific herring (Clupea pallasi) in Prince William Sound, Alaska, 1994-1995. Fish Bull 99:482-501

Sullivan RM (1980) Seasonal occurrence and haul-out use in pinnipeds along Humboldt County, California. J Mamm 61: 754-760

Taylor PJ, Goddard J (1974) Geography and statistics: an introduction. Statistician 23:149-155

Thompson PM (1989) Seasonal changes in the distribution and composition of common seal (Phoca vitulina) haul-out groups. J Zool Soc Lond 217:281-294

Thompson PM, Tollit DJ, Wood D, Corpe HM, Hammond PS, Mackay A (1997) Estimating harbour seal abundance and status in an estuarine habitat in north-east Scotland. J Appl Ecol 34:43-52

Ver Hoef JM, Frost KJ (2003) A Bayesian hierarchical model for monitoring harbor seal changes in Prince William Sound, Alaska. Environ Ecol Stat 10:201-219

Ver Hoef JM, Cressie N, Fisher RN, Case TJ (2001) Uncertainty and spatial linear models for ecological data. In: Humsaker CT, Goodchild MF, Friedl MA, Case TJ (eds) Spatial uncertainty in ecology: implications for remote sensing and GIS applications. Springer, New York

Vos DJ (2003) Cook Inlet beluga age and growth. MS thesis, Alaska Pacific University, Anchorage, AK

Watts P (1992) Thermal constraints on hauling out by harbor seals (Phoca vitulina). Can J Zool 70:553-560

Watts P (1996) The diel hauling-out cycle of harbour seals in an open marine environment: correlates and constraints. J Zool Lond 240:175-200

Willson MF, Halupka KC (1995) Anadromous fish as keystone species in vertebrate communities. Conserv Biol 9: 489-497

Womble JN, Willson MF, Sigler MF, Kelly BP, VanBlaricom GR (2005) Distribution of Steller sea lions Eumetopias jubatus in relation to spring-spawning fish in SE Alaska. Mar Ecol Prog Ser 294:271-282

Submitted: October 4, 2006; Accepted: December 21, 2006

Proofs received from author(s): June 18, 2007 